\title{
Perspectives
}

\section{JALT Journal Turns 30: A Retrospective Look at the First Three Decades}

\author{
Paul Stapleton
}

\section{Hong Kong Institute of Education \\ Paul Collett}

Shimonoseki City University

With the JALT Journal having entered its fourth decade, this retrospective of the first 30 volumes surveys some aspects of papers published in the journal, including characteristics regarding research methodology, research focus, and pedagogical level, as well as several other factors. Results of the review of 297 articles revealed that the publication has mirrored other journals in applied linguistics by adopting an empirical focus with quantitative methods being used in most of the published studies. The primary research focus was language teaching pedagogy; however, other areas receiving attention in the first three decades were pragmatics, motivation, and test reliability, with these three appearing prominently in the latter half of the 30 volumes.

JALTジャーナルが第二世代に入ったことにあたり、第一号から 30 号まで回顧し、揭載論文 の幾つかの特徵を検証する。その特徵は研究方法論、研究の焦点、そのほかの諸点における教 育学的レベルに関するものである。297編の論文を調べた結果、本ジャーナルは応用言語学の 分野で、これは最近の傾向である定性的研究ではなく、定量的研究アプローチを使った研究が 大部分であり、それらが実証的側面重視の立場を取ることにより、他の研究誌と重なっているこ とが明らかになった。当然想定されることであったが、JALTジャーナルの第一の研究主眼は語 学教育学ではあるものの、第一世代の諸論文は語用論、動機論、試験の信頼性にも関心を注 ぎ、この三つのテーマは第二世代の諸論文においても目だって取り上げられている。本再検討は またJALTジャーナルのユニークな特徵を構成する要素に深く関係するいくつかの側面にも光を 当てている。

JALT Journal, Vol. 32, No. 1, May 2010 
A $s$ in any field, language teaching has witnessed change and growth over the past generation with new approaches, frameworks, methodologies, theories, and trends. The shift in approach from the audio-lingual teaching method to more communicative-oriented teaching is just one of many examples of change within the language teaching field. Naturally, teachers and researchers have followed these shifts, although, as one would expect, the situation in Japan has developed its own individual characteristics.

The publication of the 30th volume of the JALT Journal in 2008, marking the end of the journal's third decade, appears to be an appropriate occasion to look back at the nature of the journal's first generation of research publications in order both to describe its distinctiveness and to suggest where the patterns that have emerged may be leading.

Other similar published studies have acted as a guide to the type of description and trend spotting that we attempt in this paper. With regard to reviews of research methodology, Lazaraton (2000) surveyed four prominent applied linguistics journals over a 7-year period in the 1990s, examining 332 published articles. Her findings revealed there was considerable focus on quantitative research with $88 \%$ of the studies following this methodology while only $10 \%$ were qualitative. However, Gao, Li, and Lu (2001), in a comparison of Chinese and Western language learning journals, noted that in the four Western journals they surveyed from 1985 to 1997, the number of studies using quantitative research methods went from over four times that of qualitative approaches at the outset to roughly equal numbers by 1997. More recently, Ellis (2006) noted the increasing number of qualitative articles being published in the journal he edits, Language Teaching Research. In his own small-scale survey of 25 empirical articles in the journal under his watch, he found that only $24 \%$ of the studies were quantitative while $76 \%$ were "interpretive," although some of the latter included descriptive statistics. A similar shift is noted by Magnan (2005) who, as editor of The Modern Language Journal, surveyed research articles in the same journal. Magnan revealed that from 1996 to 2005, research articles comprised 82\% of the published papers, while $18 \%$ were essays. Among the research articles, $74 \%$ were quantitative and $20 \%$ were qualitative with the remainder a combination of the two. A decade earlier, quantitative studies accounted for $93 \%$ of papers. Most recently, Benson, Chik, Gao, Huang, \& Wang (2009), in a survey of 2202 research articles in 10 leading international teaching and learning journals from 1997 to 2006 found that $22 \%$ could be classified as using qualitative research. Benson, et al. do comment that this percent- 
age should not be compared to Lazaraton (2000) or Gao et al. (2001) above because both of these considered only empirical articles at the outset, while Benson et al. included all types of articles, both empirical and nonempirical. While qualitative research appears to be finding wider acceptance in international journals within the field, it is worth noting a recent review by Richards (2009) which "revealed no evidence of a continuing expansion of [qualitative research] papers published in leading journals in our field, but the new millennium has seen consolidation to a point where its position seems secure" (p. 167), a perspective echoed by Dörnyei's (2007) claim that "applied linguistics has been offering an increasingly level playing field for both QUAN and QUAL approaches" (p. 36).

Research methodology, however is just one of many facets that define the nature of articles in a journal. Other variables include the origin and nationality of authors. Magnan (2005), for example, in the same study mentioned above, noted an increase in the percentage of non-U.S.A.-based authors with a concurrent increase in articles authored by researchers from other parts of the world, reflecting an increasing number of submissions from countries other than the United States.

Other categories that appear worthy of consideration when surveying a journal's collection of articles include:

- the level at which the research is focused (e.g., primary, secondary, tertiary

- the topic under study (e.g., pragmatics, motivation)

Thus, the primary purpose of the present study is to survey each of the main articles in JALT Journal's first 30 volumes in order to classify and summarize its nature while identifying patterns and trends which may shed light on where language teaching research in Japan is headed.

\section{Method}

The first 30 volumes of JALT Journal were examined focusing on four main areas:

- author's nationality (Japanese or non-Japanese)

- research methodology (qualitative, quantitative, or mixed methods plus instruments and statistical tests)

- level (elementary, secondary, tertiary, or other)

- $\quad$ primary topic focus

Only the 297 full-length articles were assessed in the survey, including papers in the Research Forum and Perspectives sections. Other sections, 
such as Book Reviews and Point-to-Point articles, were not included. While determining how to classify each article with regard to the above rubrics may appear straightforward, various nuances appeared in the course of the evaluation. Accordingly, we first independently scored two randomly selected volumes of JALT Journal under the categories listed above and then compared our classifications for consistency. After some negotiation, a taxonomy was established and a systematic scheme of data entry was decided.

The following conditions were set:

- Author nationality was determined by assessing first and family names. In a few cases where ambiguity arose, e.g., a non-Japanese first name but a Japanese family name, the author was deemed Japanese. In the case of multiple authors where there were both Japanese and non-Japanese names, the paper was classified under both nationalities. $^{1}$

- The methodology used in a paper was determined to be quantitative if numerical results played a role in the findings.

- The methodology used in a paper was determined to be qualitative if recognizable approaches, such as interviews, discourse or conversational analysis, observations, and documentary or transcript analysis, were employed.

- If elements of the above two methods were used, the methodological approach utilized by the author(s) was defined as a mixed methods approach.

- In order to give each paper equal weight only one central topic focus of each paper was determined, even though some papers could be viewed as having two central points. For example, in one paper (in Volume 15.2) concerning the evaluation of written errors by Japanese teachers of English and assistant (native English speaking) language teachers, the author's concern was with both the errors and native/ nonnative teachers assessment differences. We determined the latter of these to be the main focus. In these few cases, the title usually helped in making the decision.

- Papers were categorized according to their particular teaching context-was the focus of the paper on issues related to primary, secondary, or tertiary education, or had the author(s) adopted a general stance? 


\section{Results and Discussion}

In this section, we discuss prominent patterns and trends emerging from the database of 297 JALT Journal articles published between 1978 and 2008. Although many of the patterns and trends arose out of numerical counts within the categories we chose to explore, we will also bring to light qualitative information that has characterized research papers in JALT Journal's first 30 years. While a 30 -year period can be divided into several possible periods (e.g., 5- or 10-year periods), most of the analysis below focuses on JALT Journal's first and second halves (i.e., Volumes 1-15 and Volumes 1630 ). We chose this time span because it appears to best illustrate some of the major trends we explore. However, finer gradations could result in a better understanding of the trends, and in some places we mention this. The tables and figures also illustrate these finer trends in time.

\section{Nationality}

Figure 1 shows a marked increase in the number of papers from Japanese authors. Some of this increase may be due to the existence of American graduate schools in Japan conferring degrees in TESOL, as well as the increase in the number of graduate distance education programs offered by universities in the United Kingdom and Australia. The recent move in Japanese universities requiring teaching staff to apply for grants and publish research in refereed journals may be another factor.

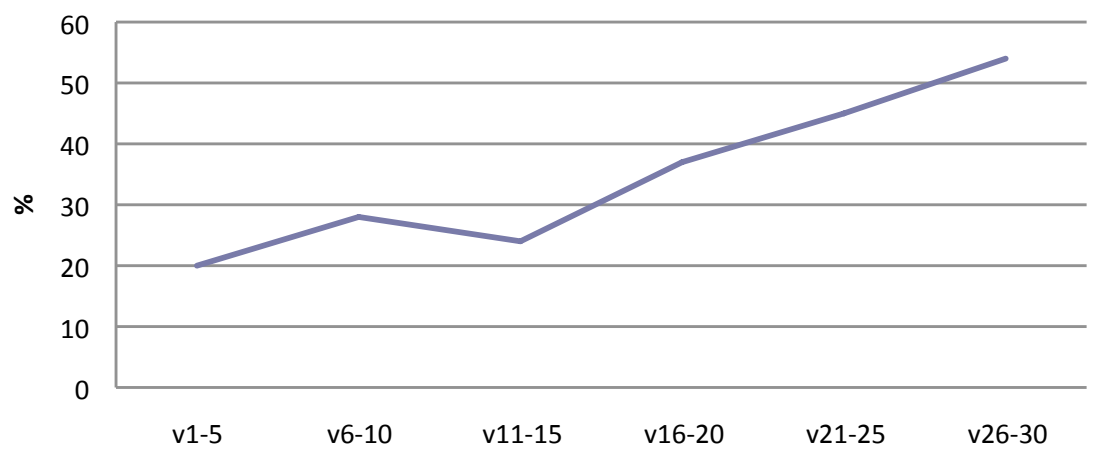

Figure 1. Japanese Authors by Percentage 


\section{Empirical Versus Nonempirical}

As applied linguistics has become established as a field of scientific study, the expectations for producing findings from empirical studies has grown. Figure 2 graphically reflects this move towards a greater emphasis on experimental, or at least data-producing, studies. Underscoring this trend, Lazaraton (2005) notes that in the 1970s and 1980s, research in applied linguistics underwent a significant move towards quantitative studies. Gao, et al. (2001) noted a similar trend in their study.

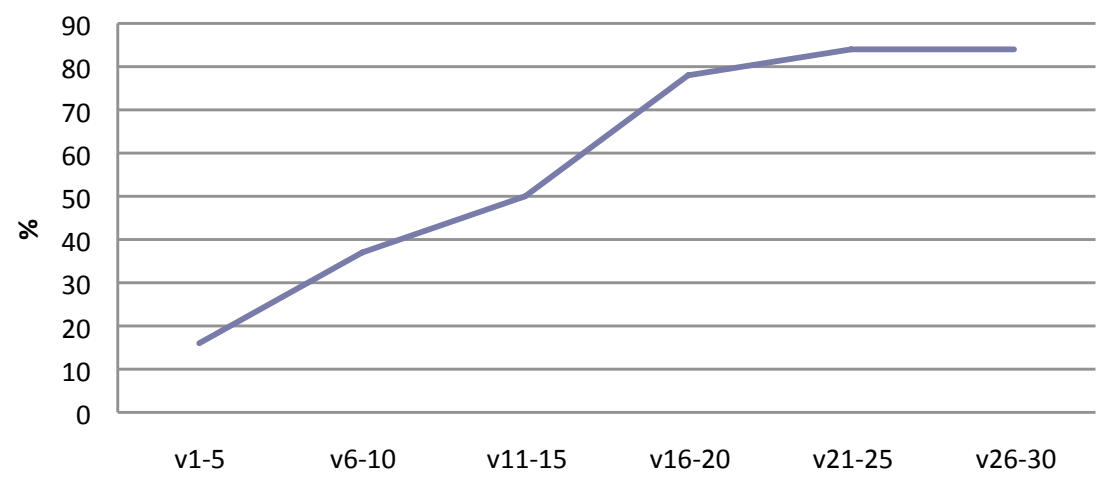

Figure 2. Percentage of Empirical Studies in Volumes 1-30

Concurrently, nonempirical articles, which can include theory-building studies, classroom techniques, critiques, and reviews, among other types of papers, have witnessed a notable decline. In the first 15 years of JALT Journal, nonempirical articles $(n=72)$ accounted for $63 \%$ of papers while in the past 15 years, they have accounted for only $23 \%(n=43)$. In the past 8 years that figure has dropped even further to $19 \%(n=16)$. Half of these appeared in the Perspectives section, which seems to serve as a venue for nonempirical papers.

Of particular interest among nonempirical studies is the large number of teaching technique pieces which appeared in the early volumes. These how to pieces, which included step-by-step instructions for classroom pedagogy, virtually disappeared in JALT Journal's second 15 years with none appearing in the past 7 years. This move away from practical pieces towards empirical studies may reflect a natural maturation of the journal towards theory and research. There may also have been recognition amongst the journal's contributing demographic that applied or pragmatic pieces were more suitable 
for submission to other teaching-oriented journals, such as The Language Teacher. A similar pattern has been noted by Stapleton and Collett (2008) in a review of submissions to JALT's other major forum for discussion of research findings, the JALT National Conference. In that study, we noted that the word data appeared in abstracts submitted to the conference in 2008 at close to double the rate of 6 years earlier.

\section{Research Methodology}

The most noteworthy pattern arising from a review of each empirical paper was the dominance of quantitative over qualitative design. In the 30 volumes, quantitative studies led qualitative ones by a factor of approximately four to one (see Figure 3). In this sense, JALT Journal content has followed a similar path to the journals mentioned above which also showed a strong skew towards studies driven by numerical data (Lazaraton, 2000). However, over the past few years, there has been a shift in this trend towards a greater proportion of qualitative studies (Figure 3). Also notable in Figure 3 is the steady increase in the percentage of mixed methods or mixed model studies, which use both qualitative and quantitative techniques, such as the use of interview data to triangulate statistical findings (Tashakkori \& Teddlie, 1998). In the past 10 years, 16 articles (about 18\% of all empirically oriented papers) incorporated both quanitative and qualitative methods within the same study. The most usual pattern among these was a questionnaire that had a Likert scale (quantitative) as well as open-ended questions (qualitative) (50\%). The second most common pattern was a Likert-style questionnaire coupled with an interview (25\%). Among these studies, similar to the findings in Benson et al. (2009), the analysis focused on the numerical data with the qualitative data used as supplementary evidence. It is interesting to note that a diverse range of authors in the social sciences have been advocating mixed methods approaches (e.g., Miles \& Huberman, 1994; Strauss \& Corbin, 1998) as well as those in SLA (e.g., Dörynei, 2007; Lazarton, 2005), reflecting a call by a number of methodologists to move away from the "paradigm wars" that have dominated discussion on methodology in the soft sciences over the last half-century towards a more pragmatic approach to research (Johnson \& Onwuegbuzie, 2004; Tashakkori \& Teddlie, 1998). The above finding may represent a growing trend in future approaches to research, a conclusion shared by Richards (2009).

Among quantitative studies, ${ }^{2}$ the most popular instrument was the questionnaire ( $40 \%, n=59)$; however, other instruments and designs were well represented including the use of language performance scores from stu- 
dents (38\%, $n=56)$, numerical scores arising from speech and text analysis including frequency counts of spoken and written texts and error analyses $(22 \%, n=32)$. The use of think-aloud protocols accounted for about $3 \%$ of the quantitative studies. The use of more than one data-producing resource resulted in percentages exceeding 100 .

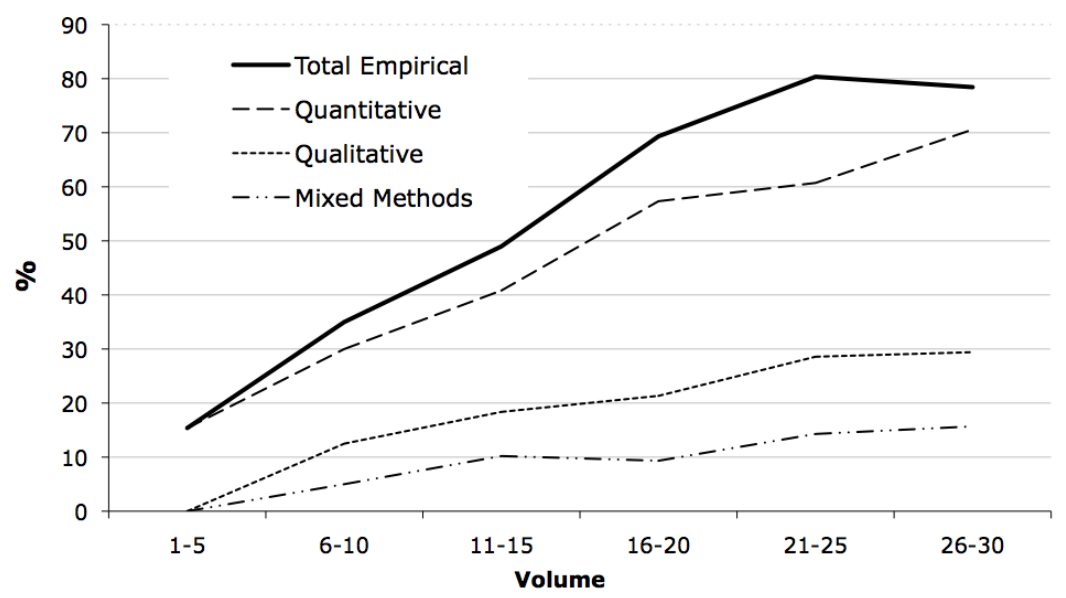

Figure 3. Methodology Type by Percentage

Over $51 \%$ of authors who chose a quantitative design employed some sort of statistical significance test $(n=76)$. The most popular among these were $t$ tests, with 35 instances (24\% of all quantitative studies) accounting for over half the statistical significance tests used, ANOVA or MANOVA $(21 \%, n$ $=31)$ and chi-square tests $(4 \%, n=6)$ in that order. Other common numerical tools included percentages $(14 \%, n=21)$; simple counts $(14 \%, n=20)$; correlations ( $8 \%, n=12)$; reliability tests (mostly Cronbach alpha) $(6 \%, n=$ 8); and means $(4 \%, n=6)$. The complexity of the statistical instruments has increased considerably when comparing the latter 15 years with the former. For example ANOVA or factor analysis was used only four times in the first 15 volumes compared to 27 times in the more recent 15. Lazaraton (2000) has noted that $40 \%$ of published studies in the four journals that she surveyed employed ANOVA, and added that if there is one statistical measure applied linguists should know how to use correctly, it is this one, due to the stringent set of assumptions underlying its use, and the possibility of misapplication.

In reporting statistical significance, the actual statistics that need to be reported has been an issue of some controversy over the past few decades; 
at least one area of consensus is that it is necessary to report the effect size (the measure of the strength of the relationship between two variables) and power (the probability of successfully finding a statistically significant difference when the difference exists). In respect to reporting effect size, the Publication Manual of the American Psychological Association (APA), 5th edition (2001) recommends

for the reader to fully understand the importance of your findings, it is almost always necessary to include some index of effect size or strength of relationship in your Results section .... The general principle to be followed ... is to provide the reader not only with information about statistical significance but also with enough information to assess the magnitude of the observed effect or relationship. (pp. 25-26)

The APA manual also states that failure to report effect size is a defect in research (p. 5), while the Task Force on Statistical Inference of the APA stated "reporting and interpreting effect sizes in the context of previously reported effects is essential to good research" (Wilkinson \& The APA Task Force on Statistical Inference, 1999, p. 599). See also Thompson (1998, 2002); Carver (1978, 1993), Shaver, (1993), Oakes (1986), and Cohen (1969) for an in-depth discussion of the issues here. In the case of JALT Journal, approximately $41 \%$ of the papers utilizing statistical significance testing published between 2001 and 2008 (2001 was the year the APA first made its stance explicit) include indices that give a measure of effect size, such as Pearson's Correlation Coefficient $r$, or eta ${ }^{2} ; 14 \%$ of the papers explicitly mention the effect size. ${ }^{3}$ In light of the kinds of comments above, is simply including a statistical result without including some mention of it in the body of the results or discussion enough? We would argue no, as it is not necessarily the case that all readers of an article will have the necessary statistical knowledge to understand clearly what a measurement is showing, or the result may get lost amongst the other data. Including a reference to effect size of a statistical significance test would help make the substantive significance of the results clearer.

Among qualitative studies, documentary analysis (including textbooks, journal entries and the like) accounted for $32 \%$ of the total $(n=20)$, followed by interviews $(27 \%, n=17)$, open-ended items on questionnaires $(23 \%, n=14)$, conversational analysis $(23 \%, n=14)$ and observations $(6 \%$, $n=4$ ). Ethnographic studies, in which a researcher becomes a participant observer who provides a thick description based on field notes triangulated 
with interviews after a lengthy engagement with subjects (Anderson-Levitt, 2006), did not appear in the data, although studies by Gorsuch (1998) and Shimada (1986) came closest to this approach.

\section{Topic Focus}

Table 1 shows the number of appearances of the most frequently researched topic areas among the 297 articles. These topic areas go a long way towards giving JALT Journal a character of its own, given the wide range of areas within ELT and applied linguistics to choose from. The frequencies in Table 1 reveal a healthy diversity of research areas. Papers focusing on teaching or methodology were by far the most common, with general theory-based discussion papers dominating the early volumes. However, there has been a clear movement away from the latter in recent years and this dovetails with the trend noted above towards increased empiricism. As the number of studies discussing pedagogy and methodology have declined, those focusing on affective factors, especially motivation, along with teachers' and learners' beliefs have increased.

\section{Table 1. Frequencies of Topic Areas}

\begin{tabular}{lccc}
\hline Topic area & $\begin{array}{c}\text { No. of } \\
\text { appearances }\end{array}$ & $\begin{array}{c}\text { First } \\
15 \text { years }\end{array}$ & $\begin{array}{c}\text { Second } \\
15 \text { years }\end{array}$ \\
Pedagogy/Methodology & 60 & 38 & 22 \\
Pragmatics & 27 & 7 & 20 \\
Motivation/affective & 21 & 3 & 18 \\
Test reliability/validity & 17 & 3 & 14 \\
Second language acquisi- & 18 & 9 & 9 \\
tion & 16 & 8 & \\
Culture & 15 & 7 & 8 \\
Learner development/ & & & 8 \\
strategies & 15 & 1 & 14 \\
Teacher/learner beliefs & 12 & 5 & 7 \\
Assessment & 6 & 0 & 6 \\
Team teaching & 4 & 0 & 4 \\
Study abroad & & & \\
\hline
\end{tabular}


Turning to the particular educational level the papers were aimed atprimary, secondary, tertiary, or non-specific-just over $49 \%$ had a tertiary focus, with only $30 \%$ of these being published prior to Volume 15 (see Table 2). Thirty-three percent of the papers were nonspecific (i.e., presenting a generalized overview or broad picture of teaching practices), with a little over two-thirds of these papers appearing in the first 15 volumes.

\section{Table 2. Frequencies of Level}

\begin{tabular}{lccr}
\hline Level & Volumes 1-15 & Volumes $16-30$ & Total \\
\hline Tertiary & 42 & 101 & 143 \\
Secondary & 4 & 46 & 50 \\
Primary & 1 & 6 & 7 \\
Nonspecific & 62 & 32 & 94 \\
\hline
\end{tabular}

Only seven papers had a primary school focus, with all but two of these appearing in the last three volumes. While this is not unexpected, due to the lack of any official foreign-language education policy at the elementary level prior to the recent implementation of compulsory English language education as set out in the Ministry of Education's updated course of study (see MEXT, 2009), it does point to an area where there may be potential for research. In fact, the impending move in Japan towards compulsory English education due to commence for 5th and 6th graders in 2011 may explain this recent interest in primary education. We expect more articles focusing on this level as English classes are added to the elementary school curriculum.

What is most interesting is the tenfold increase in papers focusing on the secondary school level over the years, perhaps reflecting a move towards an increased research-orientation within the high school English teaching profession. The authorship of these papers is fairly evenly distributed amongst non-Japanese (24 secondary school-focused papers) and Japanese authors (27); however, a greater percentage of the total number of Japanese authors have published papers with a secondary education focus than have non-Japanese.

As noted in the section on nationality of authors, the number of Japanese authors has been increasing in the past 15 years, and this trend combined with the findings above may point to an increase in the number of high 
school teachers adopting the role of research-practitioners and working to expand their professional qualifications.

\section{Ancillary Highlights}

One strong trend was a shift away from the publication of opinion or discussion pieces on pedagogy, policy, or culture that tended to dominate the earlier volumes. These generalist papers, which largely appeared in the first 15 volumes, presented broad visions of the best approach for language teaching in Japan and beyond. In more recent volumes, however, rather than attempts by practitioners to define best practices for language teaching, we are seeing more specific skills-based studies focusing on a certain level and a discrete population.

Another notable feature emerging from the study was the recent lack of published discussion or debate. Earlier issues occasionally included a section where readers submitted their reactions, usually criticism of a paper in a previous issue, sometimes leading to a lively debate in the Point to Point section. Such discussions may have disappeared for many reasons, including budget constraints or a lack of submissions; however, it is notable that this public forum no longer appears. On the other hand, this move away from debate and discussion may be a natural one given that most papers are now reports on empirical research in which broad generalizations are not offered.

Similarly, it is interesting to note that few think pieces, in which authors make broad critical comments on the profession (Bernard Susser's 1998 critique of EFL teaching was one example), have appeared in the past decade. JALT Journal does have a regular section entitled Perspectives, which may originally have been established for authors to bring perspective to the field; however, recently papers in this section have tended to be empirical (and quantitative). The academic essay gives authors the opportunity to suggest creative ways forward, and when well argued, the proposed frameworks and theories are taken on by the field. Naturally, we cannot know whether this decline in essays has occurred because of a lack of submissions in this genre or a bias among reviewers against this type of piece. We suggest that the essay does have a place in advancing knowledge, and it is worth noting that Google Scholar shows Susser's critique as one of JALT Journal's most cited papers. One other area where the Perspectives section may serve a useful function is in the running of review pieces such as Irie's (2003) survey of research on motivation within Japan. This section could provide a forum for general reports by Japan-based researchers that may not otherwise be 
accessible to a non-Japanese-language readership. Perhaps articles of this kind is one area where JALT Journal could make more of a contribution in the future.

\section{Conclusion}

There are important aspects of a journal's nature which a retrospective such as this one cannot quite elucidate. Clearly, this study looks only at papers that were published, while missing the much greater proportion of papers that were submitted, but rejected. It is difficult to precisely identify the factors that drove the patterns and trends identified in this review. For example, we have noted the dominance of quantitative studies over the 30 years, although in recent years there has been a shift towards qualitative and mixed methods studies. However, we do not know whether this is a reflection of the methodology used in the average submission, or whether it reflects the biases of the editors and reviewers over the years. Similarly, we do not know whether the recent interest in motivation and teachers' and learners' beliefs points towards a greater number of submissions in these areas or simply more interest in these topics on the part of JALT Journal reviewers. Perhaps it is a combination of both. Based on current trends, however, we can speculate that future published articles will continue the movement towards a more empirical approach informed by a more eclectic methodology, a conclusion shared by Benson, et al. (2009).

One rather blunt tool for measuring JALT Journal's impact on the field is Google Scholar's generated links to the most cited articles in the journal's collection of volumes. An advanced search using the exact phrase "JALT Journal" generates 1,640 links (as of March 2010) with the first page of 10 links all listing dozens of citations. As measures such as this one become increasingly available, reviews in the future will be able to more accurately quantify the extent and nature of a journal's impact.

For the time being, however, we can conclude that the first 30 volumes reveal that the articles published in JALT Journal have mirrored research trends in applied linguistics journals and the ELT community as a whole. The movements uncovered in this survey include the increased empiricism as evidenced by quantitative studies and more recently a move towards qualitative and mixed methods of research, both of which reflect a shift towards scientific inquiry in the field of language teaching. With this shift has come a concurrent decrease in theoretical essays and articles focusing on classroom techniques. Other trends include a steady increase in the number 
of papers published by Japanese authors and an increased diversity of topics covered. In addition to these broad tendencies, there are nuances revealed by this study of the JALT community's premier scholarly publication that uncover JALT Journal's unique contribution to language learning in Japan. We trust that this important and dynamic role will continue for yet another generation of language learners and teachers.

\section{Notes}

1. The "Nationality" category was included for indicative purposes only. Contacting each author to determine whether or not they were actually Japanese nationals was deemed beyond the scope of the present study.

2. All percentages for quantitative and qualitative studies also include those studies that used mixed methods.

3. These are figures we would expect to be similar to many other journals in the same field as JALT Journal, as it is still more common to not see mention of effect size than to see it published.

Paul Stapleton is an Associate Professor in the Department of English at Hong Kong Institute of Education.

Paul Collett teaches at Shimonoseki City University.

\section{References}

American Psychological Association. (2001). Publication manual of the American psychological association (5th ed.). (2001). Washington, DC: Author.

Anderson-Levitt, K. M. (2006). Ethnography. In J. L. Green, G. Camilli, \& P. B. Elmore (Eds.), Handbook of complementary methods in education research (pp. 279-296). Mahwah, NJ: Lawrence Erlbaum.

Benson, P., Chik, A., Gao, X., Huang, J., \& Wang, W. (2009). Qualitative research in language teaching and learning journals, 1997-2006. The Modern Language Journal, 93, 79-90.

Carver, R. P. (1978). The case against statistical significance testing. Harvard Educational Review, 48, 378-399. 
Carver, R. P. (1993). The case against statistical significance testing, revisited. Journal of Experimental Education, 61, 287-292. Retrieved from http://www.midyisproject.org/Documents/CEM/publications/downloads/CEMWeb037\%20 The\%20Case\%20Against\%20Statistical\%20Significance\%20Testing.pdf

Cohen, J. (1969). Statistical power analysis for the behavioral sciences. New York: Academic Press.

Dörnyei, Z. (2007). Research methods in applied linguistics. Oxford: Oxford University Press.

Ellis, R. (2006). Editorial. Language Teaching Research, 10, 239-243.

Gao, Y., Li, L., \& Lu, J. (2001). Trends in research methods in applied linguistics: China and the West. English for Specific Purposes, 20, 1-14.

Gorsuch, G. (1998). Yakudoku EFL instruction in two Japanese high school classrooms: An exploratory study. JALT Journal, 20, 6-32.

Irie, K. (2003). What do we know about the language learning motivation of university students in Japan? Some patterns in survey studies. JALT Journal, 25, 86-100.

Johnson, R. B., \& Onwuegbuzie, A. J. (2004). Mixed methods research: A research paradigm whose time has come. Educational Researcher, 33, 14-26.

Lazaraton, A. (2000). Current trends in research methodology and statistics in applied linguistics. TESOL Quarterly, 34, 175-81.

Lazaraton, A. (2005). Quantitative research methods. In E. Hinkel (Ed.), Handbook of research in second language teaching and learning (pp. 209-224). Mahwah, NJ: Lawrence Erlbaum.

Magnan, S. S. (2005). From the editor: The MLJ turns 90 in a digital age. The Modern Language Journal, 90, i.

MEXT. (2009). Chapter 4 Foreign language activities. Retrieved July 2, 2009, from http://www.mext.go.jp/component/a_menu/education/micro_detail/_icsFiles/afieldfile/2009/04/21/1261037_12.pdf

Miles, M. B., \& Huberman, A. M. (1994). Qualitative data analysis (2nd ed.). Thousand Oaks, CA: Sage.

Oakes, M. (1986). Statistical inference: A commentary for the social and behavioral sciences. Chichester, UK: John Wiley.

Richards, K. (2009). Trends in qualitative research in language teaching since 2000. Language Teaching, 42, 147-180.

Shaver, J. P. (1993). What statistical significance testing is, and what it is not. Journal of Experimental Education, 61, 293-316. 
Shimada, Y. (1986). The acquisition of English interrogatives by a Japanese speaker. JALT Journal, 8, 1-15.

Stapleton, P., \& Collett, P. (2008). PAC7 at JALT2008: Untangling the submission process. The Language Teacher, 32(9), 28-29.

Strauss, A. L., \& Corbin, J. (1998). Basics of qualitative research: Techniques and procedures for developing grounded theory (2nd ed.). Thousand Oaks, CA: Sage.

Susser, B. (1998). EFL's othering of Japan: Orientalism in English language teaching. JALT Journal, 20, 49-82.

Tashakkori, A., \& Teddlie, C. (1998). Mixed methodology: Combining qualitative and quantitative approaches. Applied Social Research Methods Series (Vol. 46). Thousand Oaks, CA: Sage

Thompson, B. (1998). Statistical significance and effect size reporting: Portrait of a possible future. Research in the Schools, 5, 33-38. Retrieved from http://www. personal.psu.edu/users/d/m/dmr/sigtest/4mspdf.pdf

Thompson, B. (2002). What future quantitative social science research could look like: Confidence intervals for effect sizes. Educational Researcher, 31, 25-32.

Wilkinson, L., \& The APA Task Force on Statistical Inference. (1999). Statistical methods in psychology journals: Guidelines and explanations. American Psychologist, 54, 594-604. 